\title{
Advancements in Catalytic Conversion of Biomass into Biofuels and Chemicals
}

\author{
Chang Geun Yoo ${ }^{1, *(\mathbb{D})}$ and Tae Hyun Kim ${ }^{2, *(\mathbb{D})}$ \\ 1 Department of Chemical Engineering, State University of New York College of Environmental Science and \\ Forestry, Syracuse, NY 13210, USA \\ 2 Department Materials Science and Chemical Engineering, Hanyang University, Ansan, \\ Gyeonggi-do 15588, Korea \\ * Correspondence: cyoo05@esf.edu (C.G.Y.); hitaehyun@hanyang.ac.kr (T.H.K.)
}

Received: 13 October 2020; Accepted: 14 October 2020; Published: 19 October 2020

check for updates

\begin{abstract}
The shortage of resources and increasing climate changes have brought the need for sustainable and renewable resources to people's attention. Biomass is an earth-abundant material and has great potential as a feedstock for alternative fuels and chemicals. For the effective utilization of biomass, this biopolymer has to be depolymerized and transformed into key building blocks and/or the targeted products, and biological or chemical catalysts are commonly used for the rapid and energy-efficient reactions. This Special Issue introduces recent advances in the catalytic conversion of biomass into biofuels and value-added products.
\end{abstract}

Keywords: biomass; catalysts; solvents

Over the past several decades, petroleum has been used as an essential resource in our lives. However, the rapid increase in the consumption of petroleum-based resources and environmental issues such as greenhouse gas emissions and climate change demand the use of alternative resources. Compared to other renewable sources, such as solar, wind, hydro, and geothermal, biomass has a broader spectrum of applications (e.g., biofuels, biochemicals, biomaterials). However, in order to utilize biomass, its rigid cell wall structures need to be deconstructed and selectively fractionated in advance. The cell walls of biomass are mainly composed of cellulose, hemicellulose, and lignin with other minor components such as extractives, ash, and protein. Recalcitrance factors, including crystalline cellulose, acetylated xylan, lignin, lignin-carbohydrate complex, and inorganic components, must be removed or at least reduced to some extent for effective biomass conversion [1,2].

Pretreatment is designed to eliminate these factors using various solvents and catalysts. Hydrothermal, acid, alkaline, organosolv and other methods have been applied to improve the biological conversion of cellulose and hemicellulose into biofuels and biochemicals [3-6]. Notable enhancements in enzymatic hydrolysis and fermentation were reported with these pretreatments. In addition, robust and effective biocatalysts (i.e., enzymes) and microorganisms have solved many technical problems. Unfortunately, due to the low price of petroleum-based resources these days, these bio-products are not cost-competitive by themselves.

Further enhancement of the efficiency of biomass conversion process and valorization of by-products such as lignin are the possible solutions to overcome this challenge. Several solvents, such as ionic liquids, deep eutectic solvents, molten salt hydrates, and cellulose-derived solvents, have been designed to improve the biomass conversion [7-10]. These solvents provided similar or better biomass conversion under milder conditions compared to the traditional pretreatments. Many catalysts were also designed for improving other key reactions such as hydrolysis, isomerization, hydrogenation, and oxidation of carbohydrates and lignin [11-14]. In particular, solid heterogeneous 
catalysts have much better catalyst recyclability and product separation than homogeneous catalysts and biocatalysts $[15,16]$.

Fractionation strategies for co-utilizing hemicellulose and lignin have also been studied. The fractionation process aims to separate the unnecessary components from the main product stream with high purity and yield. Therefore, finding and applying a selective as well as an effective catalyst and solvent are crucial. A biphasic solvent system [10] or co-solvent system mixed with an organic and aqueous solution [17] specifically increased the recovery of hydrophobic components (e.g., lignin) and degradation products (e.g., furfural and HMF) by preventing unwanted side reactions in aqueous environments. In addition to the high separation efficiency of each component, fractionation can preserve the quality of the separated components by minimizing their condensation and formation of pseudo-lignin.

Both solvents and catalysts play an important role in biomass conversion. This Special Issue introduces a recent catalytic biomass conversion and upgrade approaches. The published articles provide a clue to solve the technical and economic challenges in biomass utilization.

Funding: This article received no external funding.

Conflicts of Interest: The authors declare no conflict of interest.

\section{References}

1. Yoo, C.G.; Yang, Y.; Pu, Y.; Meng, X.; Muchero, W.; Yee, K.L.; Thompson, O.A.; Rodriguez, M.; Bali, G.; Engle, N.L.; et al. Insights of biomass recalcitrance in natural Populus trichocarpa variants for biomass conversion. Green. Chem. 2017, 19, 5467-5478. [CrossRef]

2. Yoo, C.G.; Meng, X.; Pu, Y.; Ragauskas, A.J. The critical role of lignin in lignocellulosic biomass conversion and recent pretreatment strategies: A comprehensive review. Bioresour. Technol. 2020, 301, 122-784. [CrossRef] [PubMed]

3. Yoo, C.G.; Nghiem, N.P.; Hicks, K.B.; Kim, T.H. Maximum production of fermentable sugars from barley straw using optimized soaking in aqueous ammonia (SAA) pretreatment. Appl. Biochem. 2013, 169, 2430-2441. [CrossRef] [PubMed]

4. Cao, S.; Pu, Y.; Studer, M.; Wyman, C.; Ragauskas, A.J. Chemical transformations of Populus trichocarpa during dilute acid pretreatment. RSC Adv. 2012, 2, 10925-10936. [CrossRef]

5. Pan, X.; Xie, D.; Yu, R.W.; Saddler, J.N. The bioconversion of mountain pine beetle-killed lodgepole pine to fuel ethanol using the organosolv process. Biotechnol. Bioeng. 2008, 101, 39-48. [CrossRef] [PubMed]

6. Ko, J.K.; Kim, Y.; Ximenes, E.; Ladisch, M.R. Effect of liquid hot water pretreatment severity on properties of hardwood lignin and enzymatic hydrolysis of cellulose. Biotechnol. Bioeng. 2015, 112, 252-262. [CrossRef] [PubMed]

7. Wang, Y.; Meng, X.; Jeong, K.; Li, S.; Leem, G.; Kim, K.H.; Pu, Y.; Ragauskas, A.J.; Yoo, C.G. Investigation of a lignin-based deep eutectic solvent using p-hydroxybenzoic acid for efficient woody biomass conversion. ACS Sustain. Chem. Eng. 2020, 8, 12542-12553. [CrossRef]

8. Liu, E.; Li, M.; Das, L.; Pu, Y.; Frazier, T.; Zhao, B.; Crocker, M.; Ragauskas, A.J.; Shi, J. Understanding lignin fractionation and characterization from engineered switchgrass treated by an aqueous ionic liquid. ACS Sustain. Chem. Eng. 2018, 6, 6612-6623. [CrossRef]

9. Meng, X.; $\mathrm{Pu}, \mathrm{Y}$.; Li, M.; Ragauskas, A.J. A biomass pretreatment using cellulose-derived solvent Cyrene. Green. Chem. 2020, 22, 2862-2872. [CrossRef]

10. Yoo, C.G.; Zhang, S.; Pan, X. Effective conversion of biomass into bromomethylfurfural, furfural, and depolymerized lignin in lithium bromide molten salt hydrate of a biphasic system. RSC Adv. 2017, 7, 300-308. [CrossRef]

11. Yoo, C.G.; Li, N.; Swannell, M.; Pan, X. Isomerization of glucose to fructose catalyzed by lithium bromide in water. Green. Chem. 2017, 19, 4402-4411. [CrossRef]

12. Shuai, L.; Pan, X. Hydrolysis of cellulose by cellulase-mimetic solid catalyst. Energy Environ. Sci. 2012, 5, 6889-6894. [CrossRef] 
13. Nagy, M.; David, K.; Britovsek, G.J.; Ragauskas, A.J. Catalytic hydrogenolysis of ethanol organosolv lignin. Holzforschung 2009, 63, 513-520. [CrossRef]

14. Schutyser, W.; Kruger, J.S.; Robinson, A.M.; Katahira, R.; Brandner, D.G.; Cleveland, N.S.; Mittal, A.; Peterson, D.J.; Meilan, R.; Román-Leshkov, Y. Revisiting alkaline aerobic lignin oxidation. Green. Chem. 2018, 20, 3828-3844. [CrossRef]

15. Behling, R.; Valange, S.; Chatel, G. Heterogeneous catalytic oxidation for lignin valorization into valuable chemicals: What results? What limitations? What trends? Green Chem. 2016, 18, 1839-1854. [CrossRef]

16. Jiang, L.; Guo, H.; Li, C.; Zhou, P.; Zhang, Z. Selective cleavage of lignin and lignin model compounds without external hydrogen, catalyzed by heterogeneous nickel catalysts. Chem. Sci. 2019, 10, 4458-4468. [CrossRef] [PubMed]

17. Cai, C.M.; Zhang, T.; Kumar, R.; Wyman, C.E. THF co-solvent enhances hydrocarbon fuel precursor yields from lignocellulosic biomass. Green. Chem. 2013, 15, 3140-3145. [CrossRef]

Publisher's Note: MDPI stays neutral with regard to jurisdictional claims in published maps and institutional affiliations.

(C) 2020 by the authors. Licensee MDPI, Basel, Switzerland. This article is an open access article distributed under the terms and conditions of the Creative Commons Attribution (CC BY) license (http://creativecommons.org/licenses/by/4.0/). 